\title{
Seasonal variations in the nutritional quality of drumstick
}

\author{
ANITTAJUDY KURIAN and P. ANITHA \\ Department of Vegetable Science, College of Horticulture, \\ Kerala Agricultural University, Vellanikkara, Thrissur - 680654, Kerala \\ Corresponding author email: anitta.judy@gmail.com
}

Drumstick (Moringa oleifera Lam.), belonging to the mongeneric family Moringaceae is one of the best useful trees with a variety of potential uses. Due to the potential of drumstick as a nutritional security provider and the high value energy crop, much importance is attached globally to this crop. Drumstick commonly known as 'horseradish tree', 'miracle tree' or 'tree of life' is native to the sub-Himalayan tracts of India, Pakistan, Bangladesh and Afghanistan (Paliwal et al., 2011). Drumstick tree is economically useful as a vegetable, natural medicine, animal fodder, natural coagulant for water purification, fertilizer, living fence, and as a bio-fuel (Pandey et al., 2012). It is a tree with minimal growth needs and can be grown in a wide range of climatic conditions, from humid tropics to arid lands. Leaves, pods and seeds are suggested as a viable supplement of digestible proteins, vitamin $\mathrm{C}$, vitamin $\mathrm{A}$, minerals like calcium, iron, magnesium, potassium, manganese, phosphorus, zinc and antioxidant compounds such as flavonoids, phenols, carotenoids, and vitamin E. Correlations of nutritional qualities of drumstick leaves with climatic factors are of great concern to the consumers. Keeping in mind that drumstick is an enormous source of nutrients, seasonal variations in the nutritional quality is of considerable important. In the present study monthly variations of nutritional quality of drumstick was investigated with a view to throw light upon correlations of nutrient profile with weather variables in drumstick.

Studies on seasonal variations in nutritional quality of drumstick were conducted during January to December 2018 at the Department of Vegetable Science, College of Horticulture, Kerala Agricultural University, Vellanikkara, Thrissur, Kerala. Twenty-five accessions of drumstick trees collected from the farmer's field and planted in the experimental field of All India Co-ordinated Vegetable Improvement Project (AICVIP) which are in $5^{\text {th }}$ year of planting were used as the experimental material for study. Nutritional qualities viz. vitamin C, protein, beta-carotene, calcium, iron and total phenols, were estimated in the leaves as detailed by Sadasivam and Manickam (1996); Srivastava and Kumar (1998). Mean data was subjected to correlation analysis using Pearson coefficient (Goulden, 1952). This enabled to understand the correlation between weather parameters and the nutritional qualities that revealed the trend in variations quality characters with changing weather conditions which can be utilized in further improvement programmes

Correlation among weather variables viz, mean temperature $\left({ }^{\circ} \mathrm{C}\right)$, mean relative humidity $(\%)$, rainfall $(\mathrm{mm})$ and number of rainy days (days) with the monthly mean values of nutritional qualities during the study period was estimated and the results are presented in Table 2. Weather data during the period of investigation are provided in Table 1.

Monthly variation of nutritional characters in drumstick leaves is given in Fig. 1. Highest mean vitamin $\mathrm{C}$ content was recorded in December $(307.84 \mathrm{mg} / 100 \mathrm{~g})$ followed by November $(270.00 \mathrm{mg} / 100 \mathrm{~g})$. Lowest vitamin $\mathrm{C}$ content was recorded in May $(154.50 \mathrm{mg} / 100 \mathrm{~g})$. Temperature is one of the most important factors that influence the vitamin C content of leafy vegetables. Negative association was estimated among vitamin $\mathrm{C}$, temperature and rainfall. Throughout the year, vitamin $\mathrm{C}$ content was poor in high temperature periods. This is in accordance with the findings of Lee and Kader (2000), that vitamin C losses are accelerated at higher temperatures in horticultural crops. High vitamin $\mathrm{C}$ content in December and lowest in May revealed that cool-dry weather condition favoured the synthesis of vitamin $\mathrm{C}$ in drumstick leaves. Thus, with less frequent irrigation, vitamin $\mathrm{C}$ content can be increased. In Indian situation, the coolest and driest time of the year is between November and February, which is regarded as the winter season, favourable for vitamin $\mathrm{C}$ accumulation.

Rainfall and relative humidity was the two climatic parameters that positively influenced the drumstick leaf protein in present study. Even though highest mean protein content in drumstick leaves was recorded in December $(20.84 \mathrm{~g} / 100 \mathrm{~g})$, the nutrient content remained almost stable for a period of 4 months from August to November which were in comparable levels with the highest value of December 
Table 1: Mean monthly weather data during 2018

\begin{tabular}{lccrr}
\hline Month & $\begin{array}{l}\text { Temperature } \\
(\mathrm{C})\end{array}$ & $\begin{array}{l}\text { Relative } \\
\text { humidity } \\
(\%)\end{array}$ & $\begin{array}{l}\text { Rainfall } \\
(\mathrm{mm})\end{array}$ & $\begin{array}{c}\text { Rainy } \\
\text { days }\end{array}$ \\
\hline January & 27.20 & 52.94 & 0.0 & 0 \\
February & 29.05 & 46.57 & 0.0 & 0 \\
March & 30.36 & 58.56 & 0.9 & 0 \\
April & 30.49 & 69.97 & 25.9 & 2 \\
May & 27.93 & 78.13 & 483.6 & 14 \\
June & 26.40 & 89.17 & 708.0 & 22 \\
July & 26.07 & 88.02 & 795.2 & 21 \\
August & 25.68 & 87.13 & 928.0 & 29 \\
September & 27.32 & 75.68 & 29.0 & 1 \\
October & 27.86 & 76.13 & 383.0 & 13 \\
November & 28.03 & 68.27 & 63.9 & 2 \\
December & 27.76 & 62.71 & 9.6 & 1 \\
\hline
\end{tabular}

(September -20.50 g/100 g). Lowest protein content was recorded in May $(16.20 \mathrm{~g} / 100 \mathrm{~g})$. Protein content in drumstick leaves showed a positive correlation with monthly relative humidity, rainfall, number of rainy days and significant, negative correlation with mean temperature. This means, high rainfall along with high relative humidity may result in accumulation of higher amount of protein in drumstick leaves. Thus, high protein content in September may be due to the heavyrainfall received in Kerala in August, 2018. Similar results on effect of leaf protein with rainfall have not been reported so far. Low protein content in May might be due to the elevated mean temperature. Studies conducted by Gulen and Eris (2004) revealed that heat stress may results in reduction of total leaf protein. Thus, concentration of leaf protein will be highest in the rainy season that normally lasts from June to September.

Environmental effects had a huge contribution to the variability in beta carotene contents in the present study. Highest mean beta-carotene content in drumstick leaves was recorded in September $(16.54 \mathrm{mg} / 100 \mathrm{~g})$ followed by November $(16.52 \mathrm{mg} / 100 \mathrm{~g})$. Lowest beta-carotene content was recorded in May $(15.10 \mathrm{mg} / 100 \mathrm{~g})$. A high temperature environment recorded poor beta carotene content across all drumstick genotypes. Significant positive correlation was observed among beta-carotene, rainfall and number of rainy days. Influence of temperature in the production of plant secondary compounds was reported by Lefsrud et al. (2005). Senescence and aging of the plant is characterized by the yellowing and falling of leaves. At the time of senescence, chlorophyll degradation occurs and carotenoid production increases, that result in yellowing of leaves. In drumstick, yellowing and falling of leaves occurs in rainy months which may be due to the degradation of chlorophyll and increased production of carotenes in leaves. High content of betacarotene was recorded in high rainfall in September, 2018. Negative correlation between beta-carotene and mean temperature might be the reason for low beta-carotene in May. Singogo (2016) reported that high temperature environment with low rainfall adversely affected the accumulation of beta carotene in storage roots of sweet potato genotypes. Since beta carotenes are essential components of the photosynthetic machinery, and play a crucial role in preventing photo oxidative damage, high temperatures accompanied by low soil moisture results in reduced activity of photosystem II (PSII), antioxidant enzyme activity and increased Reactive oxygen species (ROS) content. This will eventually lead to damage of thylakoid membrane as well as reduced yields.

Highest mean calcium content in drumstick leaves was recorded in April $(1565.97 \mathrm{mg} / 100 \mathrm{~g})$ followed by March (1304.69 mg/100 g). Lowest calcium content was recorded in August $(658.39 \mathrm{mg} / 100 \mathrm{~g})$. Calcium content showed a significant, positive correlation with mean temperature and a negative correlation with mean relative humidity, rainfall and number of rainy days. High temperature resulted in high calcium uptake whereas, high humidity and rainfall reduced it. Similar results were reported by Sud et al. (1995). Monthly trend in calcium content was irregular throughout the year. High levels in April can be explained with hot temperature of summer months. After this period, the level gradually reduced to the lowest level in August. This was the period were Kerala received highest rainfall. Later the graph continued to show the irregularity until the year end.

Highest mean iron content in drumstick leaves was recorded in August $(22.34 \mathrm{mg} / 100 \mathrm{~g}$ ) followed by July $(21.53 \mathrm{mg} / 100 \mathrm{~g})$. Lowest iron content was recorded in May $(13.31 \mathrm{mg} / 100 \mathrm{~g})$. Iron content exhibited a positive correlation with rainfall, number of rainy days and negative correlation with mean temperature. Highest iron content was recorded in August and lowest in May, might be due to the high temperature in May, 2018 which resulted in decline of iron content. Temperature plays a critical role with respect to the iron accumulation. Rivero et al. (2003) studied the influence of temperature on iron metabolism in tomato 
Table 2: Correlation of nutritional qualities and weather variables in drumstick

\begin{tabular}{lllll}
\hline Qualitative characters & Temperature $\left({ }^{\circ} \mathrm{C}\right)$ & Relative humidity $(\%)$ & Rainfall $(\mathrm{mm})$ & Number of rainy days $($ days $)$ \\
\hline Vitamin C & -0.122 & -0.068 & -0.262 & -0.233 \\
Protein & $-0.614^{*}$ & 0.158 & 0.120 & 0.126 \\
Beta-carotene & $-0.602 *$ & 0.330 & $0.640^{*}$ & $0.403^{*}$ \\
Total phenol & -0.318 & 0.027 & 0.083 & 0.066 \\
Calcium & $0.585^{*}$ & -0.356 & -0.317 & -0.343 \\
Iron & -0.300 & -0.004 & 0.157 & 0.144 \\
\hline
\end{tabular}

*. Correlation is significant at 0.05 level

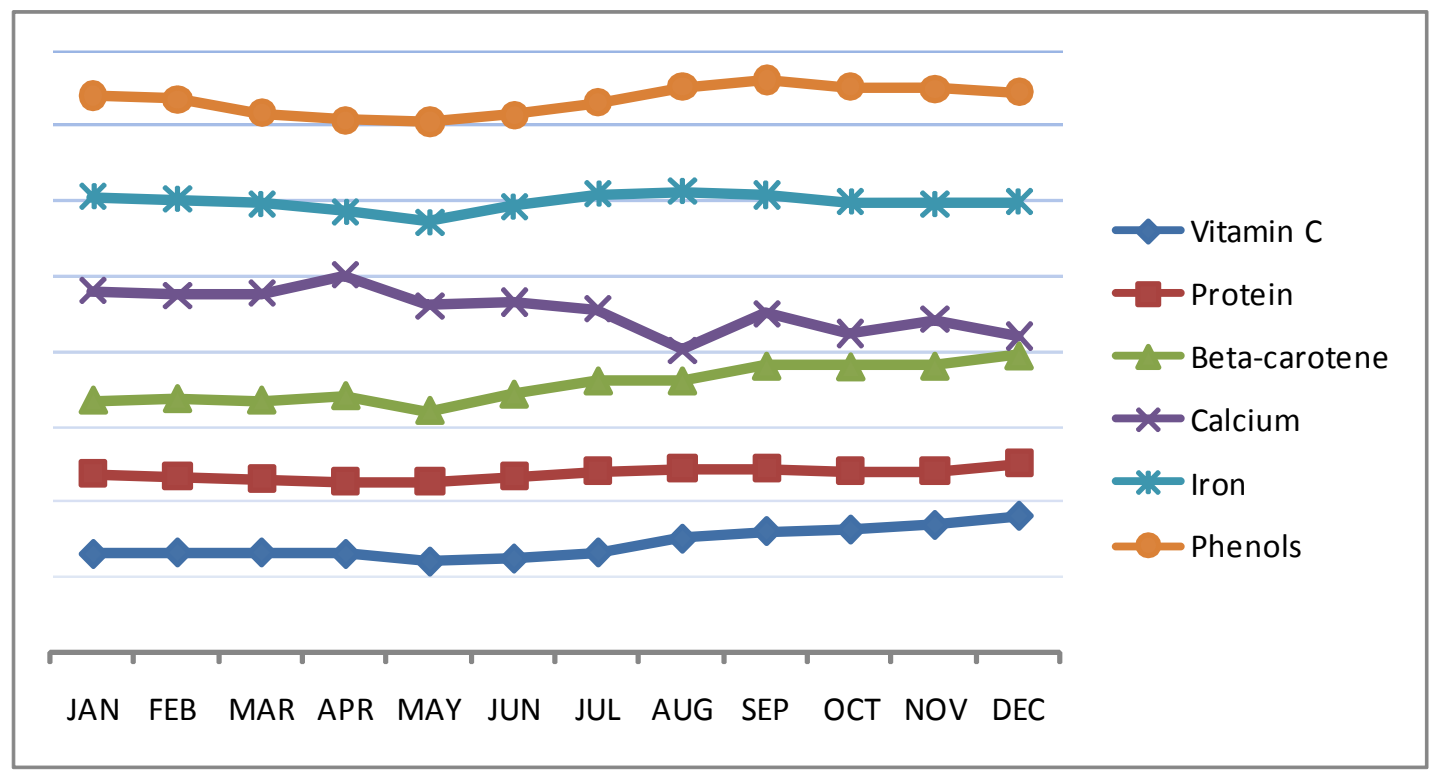

Fig 1: Monthly trend of nutritional characters in drumstick leaves

plants and found that tomato plants subjected to high temperature showed reduced iron content compared to low temperature. Thus low temperature coupled with high rainfall leads to higher iron content that coincides with rainy months. Concentrations of phenolic compounds are influenced by environmental parameters, such as soil composition, temperature, rainfall and ultraviolet radiation (Kouki and Manetas, 2002).

Drumstick is a crop with immense medicinal value and changes in phenols amounts influence directly the quality of the plant for medicinal application (Santos et al., 2006). Highest mean total phenol content in drumstick leaves was recorded in September $(124.83 \mathrm{mg} / 100 \mathrm{~g})$ followed by October $(122.90 \mathrm{mg} / 100 \mathrm{~g})$. Lowest total phenol content was recorded in May $(111.19 \mathrm{mg} / 100 \mathrm{~g})$. Total phenols recorded a declining trend throughout the summer months (March, April and May) and it was the lowest in the month of May. However, with the onset of monsoon in the month of June, total phenols showed an increasing trend and the highest total phenols were recorded in the month of September. This may be due to the heavy pouring rains recorded in month of August, 2018 which resulted in a highest accumulation of total phenols in drumstick leaves. Borges et al., (2013) conducted a study on Myrcia tomentosa, a plant with enormous medicinal properties and found that phenols content was increased with rainfall. However, consumption of drumstick leaves during rainy days might result in the high intake of total phenols. Phenols, when ingested at high concentrations may exhibit roles in genotoxicity, inhibition of iron absorption from ingested food, thyroid toxicity, and low estrogenic activity. Thus, high accumulation of total phenols during rainy period might be the reasons for avoiding the intake of drumstick leaves in rainy season. Similar results have not been reported earlier.

Focusing on the nutritional qualities of drumstick leaves, availability of highest nutritional benefits with respect to quantity and quality is a challenge to consumers. Variation 
in nutritional qualities with weather variables is a major concern. Correlation studies between nutritional qualities and weather variables revealed significant, positive correlation of calcium content with mean temperature; betacarotene with rainfall and number of rainy days. Therefore, finding of the present study enables us to focus on a particular period of the year getting desired nutrition from drumstick leaves.

\section{ACKNOWLEDGMENTS}

This paper forms a part of the MSc thesis submitted to the Kerala Agricultural University. The authors acknowledge Kerala Agricultural University for providing fund and facilities during the course of the study.

\section{REFERENCES}

Borges, L.L., Alves, S.F., Sampaio, B.L., Conceição, E.C., Bara, M.T.F. and Paula, J.R. (2013). Environmental factors affecting the concentration of phenolic compounds in Myrcia tomentosa leaves. Rev. Bras. Farmacogn. 23(2): 230-238.

Goulden, C. H. (1952). Methods of statistical analysis. 2nd ed. J. Wiley\& Sons, Inc., N.Y, 157p.

Gulen, H. and Eris, A. (2004). Effect of heat stress on peroxidase activity and total protein content in strawberry plants. Plant Sci., 166(3):739-744.

Kouki, M. and Manetas, Y. (2002). Resource availability affects differentially the levels of gallotannins and condensed tannins in Ceratonia siliqua. Biochem. Syst.Ecol., 30(7): 631-639.

Lee, S.K. and Kader, A.A. (2000). Preharvest and postharvest factors influencing vitamin $\mathrm{C}$ content of horticultural crops. Postharvest boil. Technol., 20(3): 207-220.

Lefsrud, M.G., Kopsell, D.A., Kopsell, D.E., and CurranCelentano, J. (2005). Air temperature affects biomass and carotenoid pigment accumulation in kale and spinach grown in a controlled environment. Hortic. Sci., 40(7): 2026-2030.

Paliwal, R., Sharma, V. andPracheta, S. (2011). Anti-nephrotoxic effect of administration of Moringa oleifera Lam in amelioration ofDMBA-induced renal carcinogenesis in Swiss albino mice, Biol. Med., 3: 27-35.

Pandey, A., Pandey, R.D., Tripathi, P., Gupta, P.P., Haider, J., Bhatt, S. and Singh, A.V. (2012). Moringa oleifera Lam. Sahijan)-A Plant with a Plethora of Diverse Therapeutic Benefits: An Updated Retrospection. Med. Aromat. Plants., 1 (1): 1-8.

Rivero, R.M., Sánchez, E., Ruiz, J.M. and Romero, L. (2003). Influence of temperature on biomass, iron metabolism and somerelated bioindicators in tomato and watermelon plants. J plant physiol., 160(9):1065-1071.

Sadasivam, M. and A. Manickam. (1996). Biochemical methods, 2nd Ed. New Age International Private Limited Publication, $187-188 \mathrm{p}$.

Santos, S. C., Costa, W. F., Batista, F., Santos, L. R., Ferri, P. H., Ferreira, H. D., and Seraphin, J. C. (2006). Seasonal variation tannins in barks of barbatimao. Rev. Bras. Farmacogn., 16: 552- 556.

Singogo, B. (2016). Relationship between environmental temperature and rainfall on beta carotene content and yield in selected swe et potato (Ipomoea batatas (L.) Lam.) varieties (Doctoral dissertation, University of Zambia).

Srivastava, R.P. and Kumar, S. (1998). Fruit and Vegetable Preservation- Principles and Practices. 2nd Ed. International Book Distributing Co., Lucknow, 444p.

Sud, R.G., Prasad, R., and Bhargava, M. (1995). Effect of weather conditions on concentration of calcium, manganese, zinc, copper and iron in green tea (Camellia sinensis (L) Okuntze) leaves of North Western India. $J$. Sci. Food Agric., 67(3): 341-346. 